PAwet CZAPLiŃSKI

Pomeranian University in Słupsk, Poland

\title{
Processes of Transformation of Spatial Structure of Fish Processing Industry in Poland
}

\begin{abstract}
At present fish processing industry is one of the most dynamically developing groups belonging to food industry in Poland. In the last ten years the sold production of fish processing industry increased over three times. Fish processing companies reveal a great ability to adapt to turbulently changing conditions of the market game. It happens this way, among others, as a result of creating competitiveness by widely understood consolidation processes and creating strong organizational and spatial ties of an international range. At the same time European market of fish processing guaranteed not only economic standards for already existing companies, but also became an impulse for creating new production units offering their products and services in the European Union market. The article attempts to determine the weight of factors and advantages of location for fish processing industry in Poland and their influence on the changes in the spatial structure. Besides the changes in distribution, the food processing companies in Poland were also characterized taking into consideration their concentration in view of the theory of cluster.
\end{abstract}

Key words: cluster; distribution; fish processing industry; location; spatial structure

\section{INTRODUCTION}

Within a lot of contemporary research of spatial structures of the industry, including forms of its concentration, still one of the most crucial issues seems to be the theory of location and the spatial effects connected with it, which no matter whether they refer to the new investment (greenfield) or relocation, or reconversion of the production activity, they can have different scale, rate and depth. It should be remembered that each of the companies which decides to participate in the above-mentioned processes, either in a conscious way or not, takes part in the change of the spatial structure. As a result of taking into consideration new location factors, the former (usually complex) spatial relations are established, dissolved or changed. It usually results in a new spatial organization of industrial space, not only in the scope of passive and active ties, but also relations with the direct social environment (self-government authorities, local society) and the economic one (business environment, local competition, local market) (Rachwał, 2010; Tobolska, 2011). 
At present new economic systems which are being created are based on small, flexible (in an organizational way) and creative (in a productive way) companies and due to this fact the notion 'location' is subject to significant broadening (Budner, 2007; Stryjakiewicz, 2009).

The nature of location still concerns the position of object/objects ${ }^{1}$ in space in comparison to other objects of this space, for example a communication net. However, as Stryjakiewicz (2010) writes on the basis of Dziemianowicz (2008): “(...) in Polish literature there are three directions in which a theory of location develops. The first direction concerns the regularity of creating and distribution of business activity centres. The second direction refers to the need of redefinition of spatial transaction costs in context of new socio-economic trends. The third direction of the development of location theory, mentioned by the cited authors, it is introduction to the theory of environmental factor understood as specific local conditions which influence location (...)".

At present especially popular seems to be the theory of cluster and many similar theories, partly repeated ones (for example district, circle, technopol, RSI, milieux, industrial cluster, innovative cluster, world-best cluster and others), which have been devoted a lot of research aiming at empirical version of conception. It is worth to ask question if it is already a fully shaped and matured theory (Gorynia, Jankowska, 2008; Koschatzky, 2012; Martin, Sunley, 2003).

In this context still actual seems to be a deepened reflection on methodology of geography of industry including defining basic elements of industrial space and forms of their concentration (Stryjakiewicz, 2010; Zioło, 1997, 2007, 2009).

One should agree with the thesis put forward by Z. Zioło (2008) that "the basic role in creating the spatial structure is played by consolidation processes (referring to more general polarization processes) and decentralization processes (aiming at equalizing disproportion in the scope of industrialization and dispersion of production activity)". This assumption refers to the most obvious, although much more simple definition of spatial structure, understood as distribution of certain elements in a specific area (Runge, 2006).

However, relations are the nature of spatial structure. Relations between constituent elements which may be characteristic for a specific set as a whole. It seems that the quality and quantity of relations, which O. Lange (1962) calls a "net of couplings", determine belonging to a specific spatial system.

In view of all above premises, the purpose of this article is to present factors, including location factors, which at present determine spatial systems of fish processing industry in Poland, and the attempt to describe concentration forms of this industrial group ${ }^{2}$.

Fish processing in Poland is at present one of the most dynamically developing activities of food industry. Low labour costs and high quality of products, and first of all - support

1 According to H. Godlewska (2001) the discussion concerns a single object in a micro-economic aspect. In a macro-economic view it is "searching for efficient spatial structures". It is a key selection in a context of distribution which refers to a set of objects (Budner, 2004).

${ }^{2}$ Fish processing industry (according to Polish Classification of Activities) group 10.2 - activity connected with processing and tinning fish, shellfish and mollusc. 
on the part of the Sectoral Operational Programmes 3 , contributed to success of many Polish processing companies in the domestic and European markets (for example Stanpol LLC.).

Leaders in the fish market, identified with seaside regions, evoked increased activity among lots of small food-processing plants situated in Pomerania and also among entrepreneurs from other regions of the state, till now not identified with maritime economy. There are a lot of premises which have boosted this process, among them: improvement of communication accessibility and especially many urban agglomerations of central and southern Poland, improvement of trans-shipment forms and transportation of fish (for example RSW), new ways of fish preservation, clearing distribution channels, creating a net of main fish sale (LCPSR) and many activities aiming at consolidation of fish market in the scope of fishing, processing and trade (Czapliński, 2011).

New locations of inland aquaculture enterprises are not without a meaning. This aquaculture in a considerable way supplements the offer of the maritime fish processing.

\section{ChANGES IN DISTRIBUTION OF FISH PROCESSING INDUSTRY}

Contemporary rules of food market functioning, including fish processing, provoke the reflection that location changes in the production field are necessary procedure, because on the one hand turbulent surrounding constitutes an impulse to intensify the position in the market by searching for new location benefits, and on the other hand its dynamism forces permanent revision of location decisions. The ability of the company to take advantage of its location in an optimal way, or change the location, determines the success of the company.

It seems that both ways are executed in a domestic fish industry, because on the one hand a considerable production and staff potential is distributed in coastal voivodeships, where for a long time competitive majority connected with the access to qualified staff, access to source of raw materials and also a tradition and production culture are used, and on the other hand there takes place the process of territorial transformation of fish processing industry into new or newly found regions on the basis of new or read again location factors (Fig. 1).

The amount of employment ${ }^{4}$ in fish processing industry in Poland in the years 19932011 was subject to changes between 15 thousand and 17 thousand people. On the basis of those changes there can be distinguished three periods in functioning of food processing plants and connected with those periods changes in the spatial structures of industry.

The first of them, falling in years 1993-2000, is a period in which new private food processing plants appeared. It was accompanied by taking over the technical equipment and work resources from state and cooperative companies which were in bankruptcy. The share of foreign capital turned out to be not without a meaning. Thanks to it, on the basis of the

\footnotetext{
3 "Fishery and Fish Processing 2004-2006" and "Balanced Development of the Fisheries Sector and Coastal Fishing Areas 2007-2013".

${ }^{4}$ In case of fish processing industry, it is justified to use the number of working people as the indicator of the amount of industry, due to its traditional type and high degree of labour intensity.
} 
nets of previous fish marketing boards some new food processing plants were created, for example Lisner in Poznań, Espersen Polska in Koszalin and Van den Berg Foods Polska in buildings of former Fish Marketing Board in Bydgoszcz. The process of building new plants (greenfield) or/and privatization and modernization of already existing ones (brownfield) especially dynamically occurred in the area of the present Pomorskie Voivodeship, Wielkopolskie Voivodeship and Śląskie Voivodeship. The increase in location of especially micro food processing plants was recorded in Podkarpacie and Kujawy. The process was relatively low in the area of the present Zachodniopomorskie Voivodeship. At the end of the 90's the former strategies of functioning of plants relaying on exploitation of resources were over. Most companies came into stagnation. The investment process was inhibited (Fig. 2).

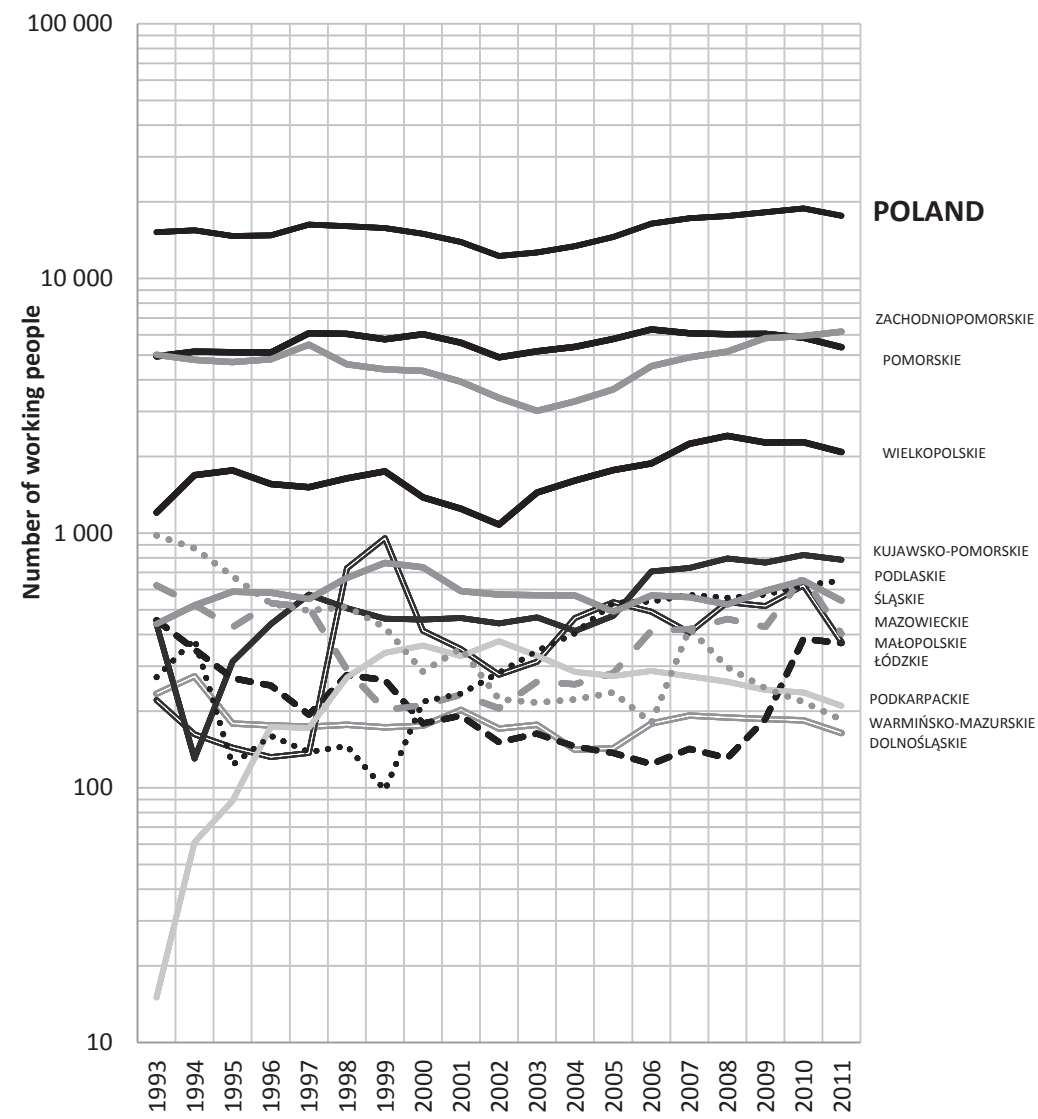

Note: due to the statistical confidentiality the data for Opolskie, Lubuskie, Lubelskie and Świętokrzyskie Voivodeships is missing in the statement

Fig. 1. People working in entities of the maritime economy in which the prevailing activity is processing and tinning fish and fishery products in the years 1993-2011 in a division into voivodeships

Source: own study based on unpublished data of the Maritime Statistics Centre in Szczecin 

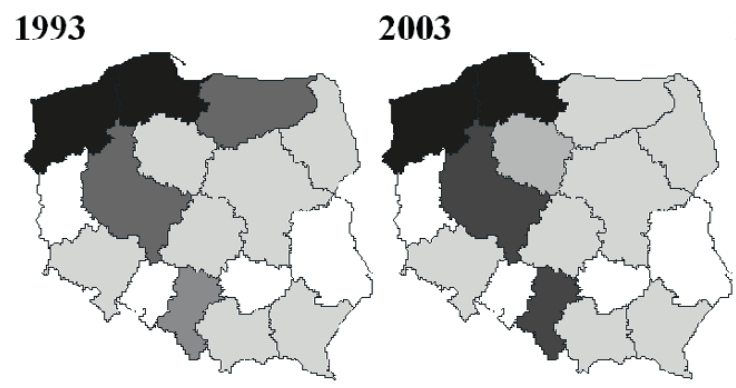

\section{1}
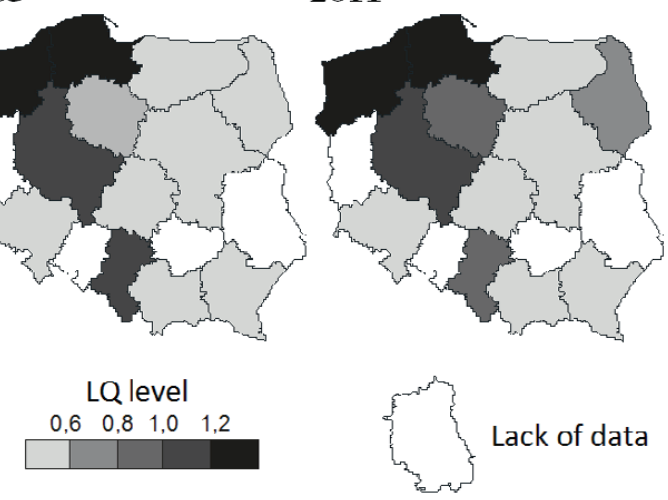

Fig. 2. Changes in spatial structure of fish processing industry in Poland on the basis of the number of working people in group 10.2

Source: own study based on unpublished data of the Maritime Statistics Centre of the Statistical Office in Szczecin

In years 2001-2004 changes of the spatial structure of Polish fish processing occurred and they were caused by the process of adaptation of fish processing to the standards of European Union. In the pre-accession period some companies took chance to obtain means in the scope of Union programmes, for example SAPARD. It is worth stressing that adaptation processes also required great engagement of own means and labour force. In this period especially creativity, independence and openness for the surrounding became an important element of competitive majority at the bottom of which was the quality of managing staff. It is among others one of the reasons of a considerable increase in employment in food processing in Mazowieckie Voivodeship, Małopolskie Voivodeship and Wielkopolskie Voivodeship and in part also in Zachodniopomorskie Voivodeship and Podlaskie Voivodeship. However, in the two previous voivodeships the increase in employment has much more complicated reason which also consisted of trans-border location, sources of obtaining raw materials or labour costs. It has to be emphasized that in case of Zachodniopomorskie Voivodeship the pre-accession period should be treated as the period of eliminating the difference in level of fish processing development and also investment processes in comparison to Pomorskie Voivodeship.

After Poland's accession to European Union a peculiar investment boom in the domestic sector of fish processing has been recorded. As a consequence of very active policy of obtaining credits and also structural funds, it has been possible to modernize and build brand new buildings. Thanks to the appropriate absorption of union funds, new locations of food processing companies has become possible for example in Zachodniopomorskie Voivodeship, Łódzkie Voivodeship and Kujawsko-Pomorskie Voiveodeship. Along with the investment processes in the mentioned voivodeships, the development has slowed down and de facto there has been a stagnation in fish processing industry in such voivodeships as: Pomorskie, Śląskie and Wielkopolskie. However, it may be explained in such a way, that 
most companies located in Pomorskie and Wielkopolskie has earlier finished the investment processes and the regional industrial area obtained a level of relative satisfaction. Especially interesting is the process of founding small food processing companies in WarmińskoMazurskie Voivodeship, which production does not exceed the region. It is accompanied by a decrease in general number of people working in food processing industry.

Regardless of the adopted criterion ${ }^{5}$ it has to be stated, that contemporary spatial structure of fish processing industry is characterized by irregularity of distribution (Fig. 3).

It is among others proved by the Florence's index of concentration ${ }^{6}$ which at the end of the first quarter of 2012 was 0.451 and the amount of Kostubiec's index ${ }^{7}$ which was determined as $86.06 \%$.

The location quotient $\mathrm{LQ}^{8}$ shows the highest concentration of fish processing companies in the coastal area - Pomorskie Voivodeship (5.13) and Zachodniopomorskie Voivodeship (3.77). However, Śląskie Voivodeship is also characterized by high concentration, but to a considerably lesser degree (1.42), and index close to high concentration is also possessed by Warmińsko-Mazurskie Voivodeship (0.98).

The results of the research prove most of the author's findings concerning locationbenefits (the rank of accessibility factors, market factors and especially the discussed human factor). However, they have regional determinants which clearly divide voivodeships

${ }^{5}$ Companies entitled to sale to the domestic market and EU market or companies entitled to sale only to the domestic market- in practice only serving the local market and in rare cases the regional market.

${ }_{6}^{6}$ The synthetic measure of spatial concentration described among others by A. Fajferk (1966):

$$
F=\frac{0.5\left|\mathrm{~W}_{\mathrm{ir}}-\mathrm{W}_{\mathrm{i}}\right|}{100}
$$

$\mathrm{W}_{\mathrm{i}}$ was calculated as a percentage share of each voivodeship in the area of the whole state,

$\mathrm{W}_{\mathrm{ir}}{ }_{\mathrm{ir}}$ was calculated as a percentage share of each voivodeship in the number of food processing plants entitled to the direct sale to the domestic market and EU market in comparison to the total number of processing plants entitled to the direct sale to the domestic market and EU market in Poland in the year 2010 .

${ }^{7}$ Kostrubiec's index was calculated on the basis of the following formula:

$$
C=\left[1-\frac{2 \mathrm{k} \times\left(\mathrm{S}_{\mathrm{x}}^{2}+\mathrm{S}_{\mathrm{y}}^{2}\right)}{\mathrm{n} \times(\mathrm{k}-1)^{2}}\right] \times 100
$$

where: $\mathrm{n}$ - number of studied objects, $\mathrm{k}$ - number of classes in the marginal distribution, $S_{x}^{2}$ $S_{x}^{2}$ - a variation of marginal distribution of number of objects at a coordinate x, $S_{y}^{2} S_{y}^{2}$ - a variation of marginal distribution of number of objects at a coordinate $y$.

${ }^{8}$ The location quotient (LQ) described among others by T. Stryjakiewicz (1999) is based on the assumption:

$$
L Q_{i}=\frac{P_{i i}}{P_{j i}}
$$

where $\mathrm{LQ}_{\mathrm{i}}$ - the location quotient fori spatial unit, $\mathrm{P}_{\mathrm{ii}}-\%$ share of $\mathrm{i}$ feature, $\mathrm{i}$ spatial unit in the unit of a higher order, $\mathrm{P}_{\mathrm{ji}}-\%$ of share of $\mathrm{j}$ feature of i $S_{y}^{2} S_{y}^{2}$ spatial unit in the unit of a higher order. According to general assumptions, when $\mathrm{LQ}<1$, then a relative deficiency of a particular feature may be assumed. 
into two groups. The fist group consists of coastal regions (Pomorskie Voivodeship and Zachodniopomorskie Voivodeship) and Warmińsko-Mazurskie Voivodeship, which as traditional places of fish processing are based on traditional location benefits resulting from the location as well as tradition and culture of manufacture. The second group consists of new regions of food processing concentration (especially Śląskie Voivodeship, to a considerable extent also southern Wielkopolskie and subsequently Kujawsko-Pomorskie and Świętokrzyskie Voivodeships). For companies of those voivodeships the most important is the target market (absorptive power, wealth, size) and also the cost factor - labour costs, transportation costs (Fig. 3).

Territorial distribution of food processing companies entitled to the direct sale only to the domestic market has a bit different spatial distribution. Less than $15 \%$ of production units of this type function in coastal voivodeships, though the highest concentration occurs in the following voivodeships: Śląskie (6.83), Lubuskie (2.56), Opolskie (2.47) and Wielkopolskie (1.17), whose total share in all companies was $56.9 \%$. The attention should be paid to a considerable concentration of plants in Warmińsko-Mazurskie Voivodeship. The reasons for distribution of companies are connected with previous arrangements concerning location benefits with the raw materials base. The development base of this type of companies are natural, favourable hydrographic conditions. Nevertheless, creating freshwater aquacultures is to a great extent determined by the human activity. In case of Opolskie Voivodeship and partly Śląskie Voivodeship, apart from natural conditions and tradition of breeding and initial processing, concentration of fish processing plants results from labour costs, favourable communication location, accessibility, wealth and volume of Silesian market. Apart from natural conditions, favourable communication location and labour costs decided on the development of aquacultures in Lubuskie Voivodeship.

A.

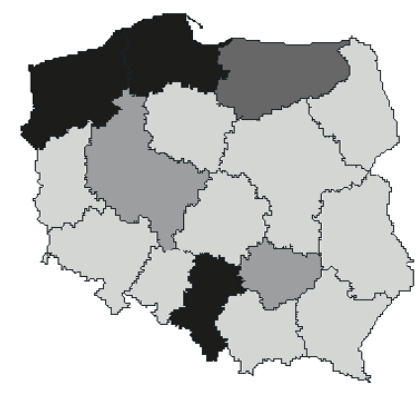

B.

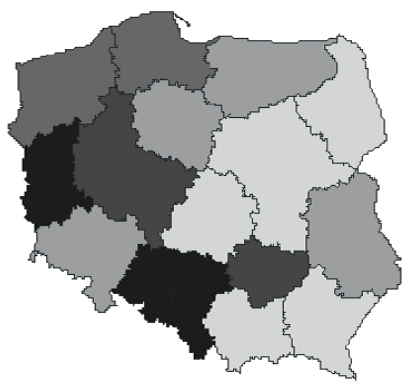

LQ level

$\begin{array}{llll}0,6 & 0,8 & 1,0 & 1,2\end{array}$

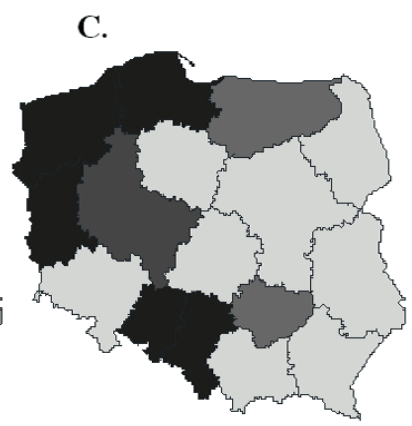

C.

0,6

A. to the domestic market and EU market in 2011; B. to the domestic market in 2011; C. total A+B

Fig. 3. Spatial structure of fish processing industry in Poland on the basis of distribution of companies Source: self-study on the basis of the data of the Main Veterinary Inspectorate 
Moreover, interesting is the fact of considerable development of companies of the whole group, which took place after the year 2006. Its determinant was the start of the operational programme "Sustainable Development of the Fisheries Sector and Coastal Fishing Areas 2007-2013", and especially the second priority axis connected with the investments concerning the aquaculture and inland fishing. Thanks to the above, on a state scale, 446 production units of this type functioned at the end of the first quarter of 2012, while in the year 2005 it was only about 50 production units.

In presented analysis a process of spatial transfer in fish processing industry is visible. As a result of coming into existence, a considerable number of new food processing companies beyond coastal regions appears (at a relatively small number of newly created companies in these regions) and a decrease in the share of food processing companies of coastal regions in Polish fish processing industry takes place. It happens mostly for the benefit of such voivodeships as: Śląskie, Wielkopolskie and Lubuskie (Tab. 1, Fig. 4).

Tab. 1. The share of fish processing companies* distributed in Pomorskie and Zachodniopomorskie Voivodeships in the total number of food processing companies in the state

\begin{tabular}{|l|l|l|l|l|l|l|l|}
\hline Years & 2006 & 2007 & 2008 & 2009 & 2010 & 2011 & 2012 \\
\hline $\begin{array}{l}\text { The share of fish processing companies of } \\
\text { coastal regions in Polish fish processing } \\
\text { industry (in \%) }\end{array}$ & 62,0 & 59,3 & 58,2 & 58,5 & 57,6 & 54,5 & 54,5 \\
\hline
\end{tabular}

*it refers to companies entitled to sale to the domestic market and EU market

Source: self-study on the basis of Market Analysis - Fish Market, No. 1-17, IERiGŻ, Warsaw

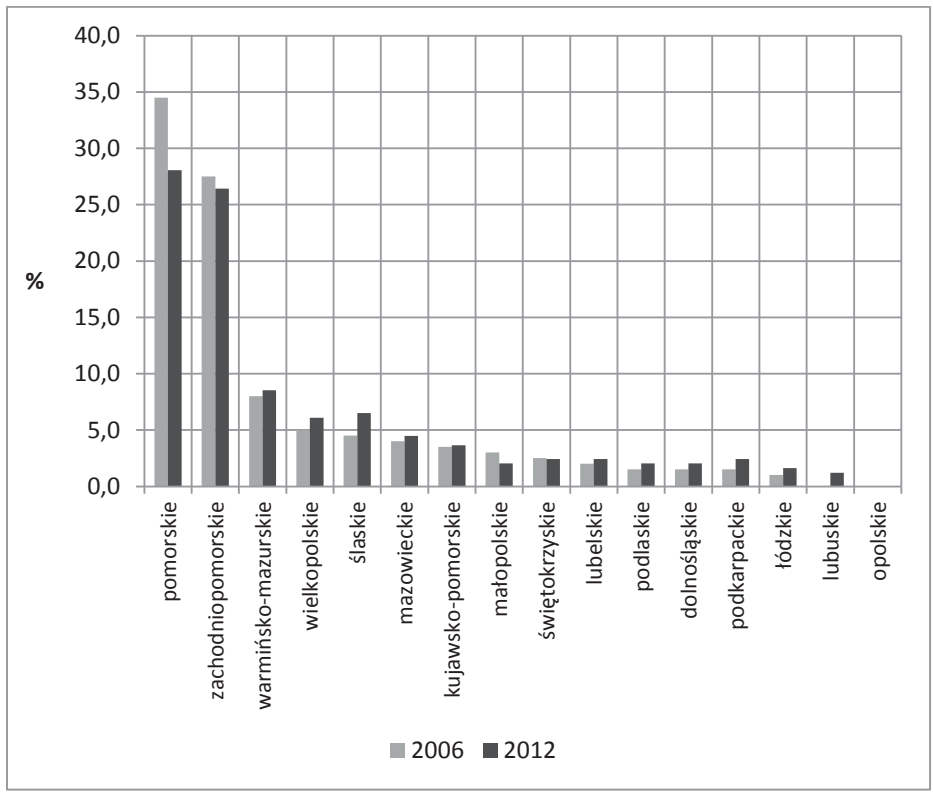

Fig. 4. Changes in the number of companies of fish processing industry in years 2006-2012

Source: own study 
The spatial structure of fish processing companies in Poland provokes reflection on forms of spatial concentration of units.

It seems that food processing companies form visible concentrations ${ }^{9}$ of different number and area. The most numerous and the biggest ones in respect of the area occur in coastal voivodeships. It is, however, worth paying the attention to the fact that production units of fish processing industry also show the ability to concentrate in other regions. Special attention should be paid to: Śląskie Voivodeship (Śląsk and Częstochowa concentration), to the border of Mazowieckie and Kujawsko-Pomorskie Voivodeships (Płock and Włocławek concentration), to Warmińsko-Mazurskie Voivodeship (Warmia concentration and Olsztyn concentration), to Podkarpackie Voivodeship (Rzeszów concentration) and Wielkopolskie Voivodeship (Kalisz concentration). The distribution of concentration of fish processing industry in Poland, though it does not have to prove the strong ties between them, may be a starting point for a discussion on functioning of a cluster (clusters) of fish processing industry in Poland.

In the theory of cluster not without a meaning is a geographical neighbourhood ${ }^{10}$ (Ketels, 2004; Porter, 2001).

Closeness of units is not the sufficient condition to identify the cluster, nevertheless it is a crucial premise for its occurrence. One should agree with the thesis by T. Brodzicki, D. Ciołek and M. Tarkowski (2012), that: "the probability of occurring the interaction between entities increases both with the increase in the number of entities and also with the decrease in the distance between independent economic entities".

So it seems that a part of determined concentrations may in the future create local industrial clusters. It is important whether entrepreneurs of fish sector are aware of the benefits of cluster initiatives (increase in competitiveness through innovativeness among others, increase in mobility of resources including the capital, reduction of transaction costs, economies of scale). According to the author's research, the process of creating a cluster (clusters) of fish processing industry has already begun, but it is in an initial stage (stage of incubation) in comparison to other industries connected with the market analysis and initial mapping.

The distinguished concentrations of fish processing companies are at a different stage of creating connections based on interrelations, co-operation, awareness and trust. In this context, we can distinguish the so-called unaware clusters (for example Słupsk cluster of fish processing) or potential clusters (for example Silesian one). It is assessed that at least half of them could become fully functioning clusters after exceeding the critical mass (number of entities and interactions connecting them). There are also examples of clusters which may be acknowledged as already aware clusters - such as fish cluster in Szczecin (Ćwiałkowska, 2011).

It results from the definition by M.E. Porter (2001: 248) that "the geographical range of a cluster may include one city, province or the whole state and even a group of neighbouring states".

9 A term concentration has been used in a meaning of co-existence of identified (in terms of quantity) groups of companies, where the distance between the closest two units does not exceed $20 \mathrm{~km}$.

10 Therefore, it is worth asking the question, whether and to what extend the geographical closeness means territorial continuity or/and spatial density, since "the geographical range of a cluster may include one city, province or the whole state and even a group of neighbouring states" (Dutkowski, 2005: on the basis of Porter, 2001: 248). 
At this stage of discussion it is worth to ask the question: whether fish processing industry in Poland may be treated as a domestic cluster?

The following assumptions are in favour of the above:

1) geographically common resource base (for example Norway),

2) applying similar technologies of processing, tinning, packaging and transportation, and as a consequence homogeneousness of a product,

3) similar organizational solutions in the scope of the sale of ready-made products (distribution networks and commercial networks),

4) consolidation process and/or fragmentation of production in the scope of capital groups,

5) common environment for fish processing $B+R$,

6) strong export orientation (about $90 \%$ of the turnover value).

The above-mentioned facts and also the proceeding process of time-space compression resulting from the global processes give rise to the discussion over functioning of fish processing industry in Poland as a non-metropolitan dispersed cluster of low technology.

\section{Conclusions}

The presented facts which concern identification of key location factors and consequences of spatial location decisions lead to the following conclusions:

1) The process of deconcentration concerns mostly the decrease in the amount of fish processing potential in coastal voivodeships (Pomorskie and Zachodniopomorskie Voivodeships). However, it has to be stressed that the rate of the process is slow and in a short term prospect it does not cause crucial statistical changes in current spatial structure of the studied industrial group. It is worth paying attention to new locations, especially of small companies in regions, which so far has not been associated with fish processing.

2) New locations of companies and also organizational and ownership changes (among others relocation) within units already existing have caused to come into existence "new" or reformate "old" concentrations of food processing companies. A new activity formula might be based on the theory of cluster. However, the process of creating them on the state scale is rather at the stage of incubation and the idea of the domestic cluster is rather theoretic.

\section{POSTSCRIPT}

As it results from the announcement of the representatives of the Ministry of Agriculture and Rural Development ${ }^{11}$ in a new programming period (2014-2020) fish processing industry

${ }_{11}$ The opinion of Janusz Wrona, deputy director of Fisheries Department of Ministry of Agriculture and Rural Development, expressed during Słupsk Economy Days on 12.10.2012. 
in Poland will not receive a considerable support. The basic reason for this decision is its modernity and high competitiveness towards companies from other EU states.

Does it mean that the development process and further changes in spatial structure of fish processing in Poland will be suspended?

\section{References}

Brodzicki, T., Ciołek, D., Tarkowski, M. (2012). Mapowanie klastrów w Polsce - próba dostosowania metody. In: T. Brodzicki, J. Kuczewska (eds.), Klastry i polityka klastrowa $w$ Polsce. Konkurencyjność przedsiębiorstw, sektorów i regionów. Gdańsk: Wydawnictwo Naukowe UG, 60-98.

Budner, W. (2004). Lokalizacja przedsiębiorstw. Aspekty ekonomiczno-przestrzenne i środowiskowe. Poznań: Wydawnictwo Naukowe AE.

Budner, W. (2007). Czynniki lokalizacji inwestycji a możliwości rozwoju ekonomicznego gmin w Polsce. Acta Scientiarum Polonorum, Administratio Locorum, 6, 43-58.

Czapliński, P. (2011). Funkcjonowanie przemysłu przetwórstwa rybnego w Polsce w okresie kryzysu gospodarczego. Prace Komisji Geografii Przemystu Polskiego Towarzystwa Geograficznego, 17, $114-128$.

Czapliński, P. (2012). Consolidation strategy in the polish fishing industry in the light of globalization processes and the European integration. In: P. Slaveykov (ed.), Security in the age of global changes. Sofia: University St. Kliment Ohridski, 236-240.

Ćwikałowska, A., Pieńkowski, M., Przybyłowski, M., Rybacka, M., Szultka, S., Tamowicz, P., Walkiewicz, D. (2011). Istniejace klastry i inicjatywy klastrowe w województwie zachodniopomorskim. Szczecin-Gdańsk: Wydawnictwo IBnGR, ICG.

Dziemianowicz, W. (2008). Konkurencyjność gmin w kontekście relacji władze lokalne - inwestorzy zagraniczni. Warszawa: Wydawnictwo Naukowe UW.

Dutkowski, M. (2005). Klastry w ujęciu regionalnym. Biuletyn PAN Komitetu Przestrzennego Zagospodarowania, 219, 57-73.

Fajferek, A. (1966). Region ekonomiczny $i$ metody analizy regionalnej. Warszawa: Wydawnictwo PWE.

Godlewska, H. (2001). Lokalizacja działalności gospodarczej. Wybrane zagadnienia. Warszawa: Wydawnictwo Naukowe WSHiFM.

Gorynia, M., Jankowska, B. (2008). Klastry a konkurencyjność i internacjonalizacja przedsiębiorstw Wielkopolski. Gospodarka Narodowa, 5-6, 91-109.

Lange, O. (1962). Całość i rozwój w świecie cybernetyki. Warszawa: Wydawnictwo PWN.

Ketels, Ch. (2004). European Cluster. Structural Change in Europe 3 - Innovative City and Business Regions. Bollschweil: Hagbarth Publications.

Koschatzky, K. (2012). Cluster quo vadis? The future of the cluster concept. Working Papers Firms and Region, 1, 1-13.

Martin, R., Sunley, P. (2003). Deconstructing clusters: Chaotic concept or policy panacea? Journal of Economic Geography, 3, 5-35.

Porter, M.E. (2001). Porter o konkurencji. Warszawa: Wydawnictwo PWE.

Runge, J. (2006). Metody badań w geografii społeczno-ekonomicznej. Katowice: Wydawnictwo Naukowe UŚ.

Rachwał, T. (2010). Struktura przestrzenna i działowa przemysłu Polski na tle Unii Europejskiej w świetle wybranych mierników. Prace Komisji Geografii Przemystu Polskiego Towarzystwa Geograficznego, 16, 105-124.

Stryjakiewicz, T. (1999). Adaptacja przestrzenna przemyshu $w$ Polsce $w$ warunkach transformacji. Poznań: Wydawnictwo Naukowe UAM. 
Stryjakiewicz, T. (2009). Nowe spojrzenie na czynniki lokalizacji działalności gospodarczej. In: I. Jażewicz (ed.), Wspótczesne problemy przemian strukturalnych przestrzeni geograficznej. Słupsk: Wydawnictwo Naukowe AP, 94-102.

Stryjakiewicz, T. (2010). Przemiany w geografii przemysłu. Prace Komisji Geografii Przemystu Polskiego Towarzystwa Geograficznego, 15, 30-44.

Tobolska, A. (2011). Czynniki lokalizacji fabryk wybranych korporacji międzynarodowych w Polsce. Biuletyn IGSEiGP, 15, 55-67.

Zioło, Z. (1997). Miejsce struktury przestrzennej przemysłu w przestrzeni geograficznej. In: B. Domański (ed.), Geografia-Człowiek-Gospodarka. Kraków: Wydawnictwo Naukowe UJ, 13-19.

Zioło, Z. (2007). Zarys koncepcji budowy teorii struktury przestrzennej przemysłu. In: Z. Zioło, M. Borowiec (eds.), Problematyka XII Ogólnopolskiej Konferencji Naukowej nt. Problemy metodologiczne geografii przemystu. Warszawa-Kraków: Wydawnictwo UP, 14-20.

Zioło, Z. (2008). Problemy badawcze struktury przestrzennej przemysłu. Prace Komisji Geografii Przemystu Polskiego Towarzystwa Geograficznego, 11, 9-25.

Zioło, Z. (2009). Model badań procesu transformacji elementów przestrzeni geograficznej. In: I. Jażewicz (ed.), Współczesne problemy przemian strukturalnych przestrzeni geograficznej. Słupsk: Wydawnictwo Naukowe AP, 103-118.

Pawel Czapliński, Ph.D., graduate of geography in the Management and Economy department at Gdańsk University of Technology. Doctor of Geographical Sciences at Pedagogical University of Cracow (2004). In years 1996-2004 assistant and then associate professor in the Institute of Geography and Regional Studies at Pomeranian University in Słupsk. Secretary of the Editorial Committee of Słupsk Geographical Works and member of the editorial board of journals: Prace Komisji Geografii Przemysłu Polskiego Towarzystwa Geograficznego and Przedsiębiorczość - Edukacja. Author of more than seventy publications and monographs with subjects of transformation of spatial structures of industry in Northern Polish, performance and prospects of the development of the fish processing industry in Poland, entrepreneurship of young people and the elderly in rural areas, and some aspects of the management and administration of local government.

\section{Adres/address:}

Pomeranian University in Słupsk

Institute of Geography and Regional Studies

ul. Partyzantów 27, 76-200 Słupsk, Poland

e-mail: somma@o2.p 